\title{
Reproduction of the endangered endemic saffron coral to the Gulf of California Porites sverdrupi (Anthozoa: Scleractinia): implications for its long-term maintenance
}

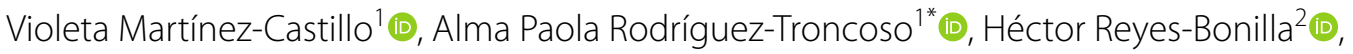 \\ Carlos Augusto Aguilar-Cruz $z^{3}$ and Carlos Rangel-Dávalos ${ }^{4}$
}

\begin{abstract}
The biology of the scleractinian Porites sverdrupi, endemic to the Gulf of California, is poorly studied. In order to fill that gap, the present study documents the reproductive biology of this coral which is to date protected by the IUCN's as "vulnerable" and listed as "in risk of extinction" in the Mexican Federal Law for species protection. Also, potential distribution models were constructed to evaluate the status of the remaining species' populations, and the role that reproduction has in their permanence. Porites sverdrupi show a gonochoric brooding reproductive pattern, with asynchronous gamete development regulated by sea surface temperature and light. The potential distribution models suggest that this coral currently covers less than $6 \%$ of its original range of distribution. Furthermore, the results suggest that, despite the drastic decline of the species, the remaining populations have the ability to persist even under current changing ocean conditions as successful sexual reproduction was documented even during the strong 2014-2015 ENSO event producing sexual recruits to maintain themselves.
\end{abstract}

Keywords: Coral reproduction, Ecological niche, Potential distribution, Coral conservation

\section{Introduction}

Sexual reproduction in corals has been widely studied as a fundamental process that contributes to the maintenance of populations [1], increases their resilience [1], and promotes long distance dispersal [2]. It is considered a key factor for coral development and survival in isolated regions [2], such as the Eastern Tropical Pacific (ETP [3]), where corals live under extreme environmental conditions such as low $\mathrm{pH}$, high sedimentation, nutrient pulses, and wide ranges of sea surface temperature [4]. Furthermore, successful reproduction

\footnotetext{
*Correspondence: pao.rodriguezt@gmail.com

1 Laboratorio de Ecología Marina, Centro Universitario de la Costa,

Universidad de Guadalajara, Av. Universidad 203, Delegacion Ixtapa, 48280 Puerto Vallarta, Jalisco, Mexico

Full list of author information is available at the end of the article
}

and recruitment of corals is essential for reef recovery in this region after ENSO events $[5,6]$ which are increasing in both frequency and intensity with the consequent massive bleaching and mortality events $[7$, 8].

Gamete production and maturation of the main reef building coral families such as Pocilloporidae, Poritidae, and Agariciidae, in the ETP are associated to the warm season, usually from May to September [9, 10], and some Porites corals may even produce gametes throughout the year [10]. In the area, most scleractinians have been described as spawning corals, both gonochoric or hermaphrodite, and there is only one known brooder species, Porites panamensis Verrill, 1866 [9]. The Mexican Pacific (MP) represents the northernmost East Pacific distribution limit for hermatypic corals, a region 
influenced by strong annual changes in sea surface temperature caused by the convergence of the cold California Current, the warm Mexican Coastal Current, and the warm and high salinity waters from the Gulf of California (GC [11]).

Even though the reproductive patterns of the most abundant coral species in the MP have been previously characterized $[9,12,13]$, there is still no information about the reproductive biology of several taxa, including endemic species such as the saffron coral Porites sverdrupi Durham, 1947, a free living scleractinian (i.e. that does not attach to the substratum) usually associated to rhodolith beds [14] at depths from 1 to $40 \mathrm{~m}$ (Fig. 1, [15]). The historical geographic distribution of the species in Mexico ranges from Islas Marias $\left(20^{\circ} \mathrm{N}\right)$ to Isla Angel de la Guarda (29 N, Fig. 2a, [16]), however, a rapid and constant decrease in populations has been recorded since the early 1990's as a consequence of bleaching events and hurricanes [17, 18]. Currently, only three extant healthy populations can be found along the GC: one at San Lorenzo Channel, La Paz Bay $\left(24^{\circ} \mathrm{N}\right)$, and others at Isla Catalana, Loreto Bay $\left(25^{\circ} \mathrm{N}\right)$, and El Requeson Beach, Concepcion Bay $\left(26^{\circ} \mathrm{N}\right.$; Fig. 2b, [16]).

It is well known that a low population density and a reduced geographic range may increase the susceptibility and vulnerability of any species [19]. Because of its currently reduced distribution, susceptibility to disease, habitat degradation, and high sea water temperatures in the area associated to ENSO events, Porites sverdrupi is categorized as "vulnerable" by the IUCN Red List of Threatened Species [15] and listed as "in risk of

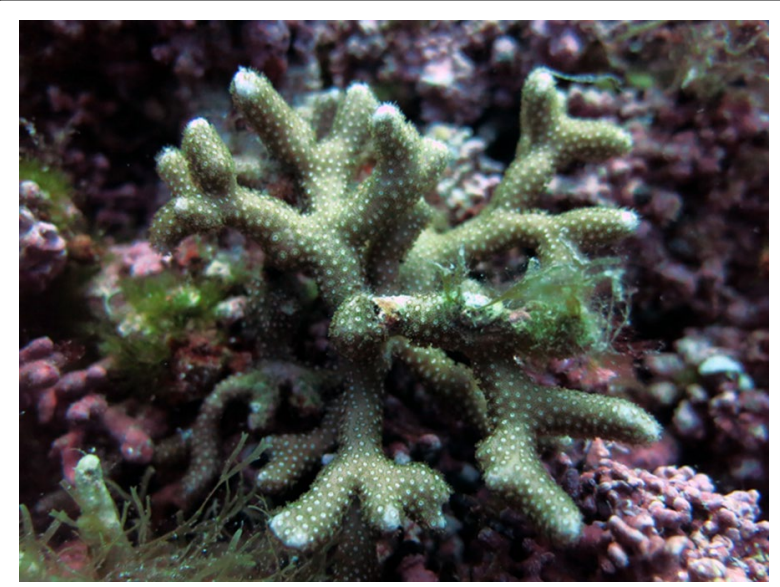

Fig. 1 Porites sverdrupi coral colony at the rhodolith bed in Isla Catalana. Photography courtesy of Sara M. Melo-Merino
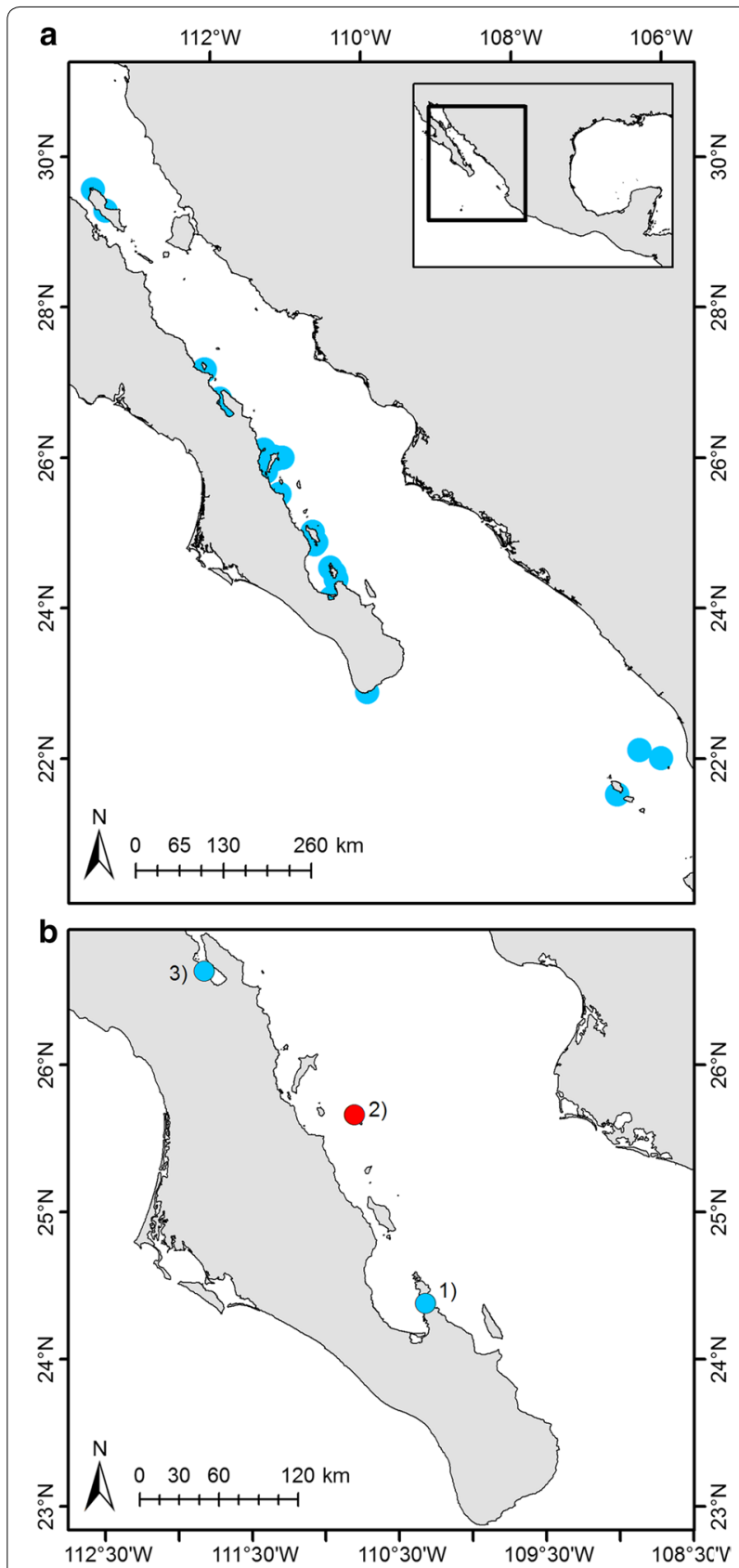

Fig. 2 Porites sverdrupi distribution in the Gulf of California: a historical occurrences of the species, $\mathbf{b}$ sites with extant populations of P. sverdrupi: 1-San Lorenzo Channel, La Paz Bay; 2-Isla Catalana, Loreto Bay; 3-El Requeson, Concepcion Bay

extinction" in the NOM-059-SEMARNAT-2010, the official Mexican regulation for endangered species. Therefore, it is highly relevant to understand life history processes, such as reproduction and its relation to environmental conditions, since this is a key process 
that needs to be considered by stakeholders for management and conservation strategies.

\section{Materials and methods}

A total of 355 Porites sverdrupi adult colonies of $\sim 5-10$ of maximum diameter $\mathrm{cm}$ were collected across the 20 months of sampling, from May 2014 to December 2015, from a rhodolith bed at a depth of $20 \mathrm{~m}$ at Isla Catalana, Mexico $\left(25.66366^{\circ} \mathrm{N}, 110.80469^{\circ} \mathrm{W}\right.$; Fig. 2), $25 \mathrm{~km}$ east off the Baja California peninsula, in the central region of the GC.

The site of collection presents a higher density of coral colonies ( $>70$ colonies per $\mathrm{m}^{2},[20]$ ) compared to other extant populations in the GC [16]. Between 16 and 26 free-living colonies (i.e. they are unattached to the substratum) were collected by SCUBA diving, fixated in 5\% formaldehyde and transported to the laboratory where they were stored at room temperature until further processing. Corals were decalcified using a solution of $10 \% \mathrm{HCl}, 0.7 \mathrm{~g}$ EDTA, 0.14 g sodium tartrate, and $0.008 \mathrm{~g}$ sodium potassium tartrate [21]. The decalcified tissues were rinsed in tap water for $24 \mathrm{~h}$ and preserved in $70 \%$ ethanol [21]. Following preservation, tissues from each sample were processed in a Tissue Processor (Tissue-Tek $\mathrm{II}^{\circledR}$ ) and embedded in paraplast [22]. Histo-slides of $5 \mu \mathrm{m}$ in thickness were produced using a rotation microtome (Leica ${ }^{\circledR}$ RM 2125RT) and stained with Harris' hematoxylin and eosin [23]. Resulting histo-slides were analyzed using a compound microscope (Nikon 21 Optiphot-II ${ }^{\circledR}$ ) identifying the sex of each colony and gametocyte development status according to Glynn et al. [21]. Gametes were photo documented and the mean \pm standard error of observed oocytes and nuclei were measured using the software AxioVision ${ }^{\circledR}$ v.4.8. Sex ratio was evaluated using a Chi square test for equality of proportions with the total number of female and male colonies sampled [24].

During the study, four environmental variables were selected to evaluate their influence in the reproduction of $P$. sverdrupi: mean monthly sea surface temperature (SST), photosynthetically active radiation (PAR), light attenuation coefficient ( $\mathrm{kd}$ at $490 \mathrm{~nm}$ ), and chlorophyll $a$ concentration ( $\mathrm{chl} a$ ) values. For all environmental variables, data were obtained from images of the MODISAqua satellite at a resolution of $4 \mathrm{~km}$ taken in the general area of presence of the coral population at Isla Catalana from the GIOVANNI database of the National Aeronautics and Space Administration of the United States [25]. Each reproductive stage was cross-correlated according to Davies [26] with the environmental data using Past v3 software [27] to observe if gamete production and maturation in $P$. sverdrupi is linked to these variables. In these analyses, a positive lag means that as the environmental conditions change (e.g. as temperature rises), gamete production begins, and hence reproduction is linked to the variable analyzed. Historical satellite data was used for the construction of potential distribution models as well.

Finally, to determine the vulnerability of this threatened species [15, CITES id 9120], the ecological niche and potential distribution of the species $P$. sverdrup $i$ was modeled in MaxEnt software v3.3.3 k [28] under three different scenarios: (1) the representation of the historical distribution; (2) the constraints after the first extinction events in the southern GC, and; (3) the consequent distribution of the species to date. To build such models, historical occurrences were obtained from local records [29], the Ocean Biogeographical Information System [30], the Global Biogeographical Information Facility [31], and from field excursions (this study).

Repeated occurrences were discarded before the analyses to avoid overparameterization of the models [32] and were built using the annual values of minimum, maximum, mean, and range of environmental variables as follows: oxygen, salinity, silicate, phosphate, and nitrate concentrations from 1990 to 2010 were gathered from the World Ocean Atlas 2013 [33], while sea surface temperature, chlorophyll $a$ concentration, the coefficient of light extinction ( $\mathrm{kd}$ at $490 \mathrm{~nm}$ ), and depth of euphotic zone were obtained from satellite information (2002 to 2015) through the National Aeronautics and Space Administration of the United States [25]. Alkalinity was estimated using temperature and salinity values [34], while $\mathrm{pH}$ and the aragonite concentration were calculated with CO2SYS software using temperature, salinity, silicate, nitrate, and atmospheric concentration of carbon dioxide [35]. Last, the type of coast was included as an environmental variable to characterize the habitat as either rocky or sandy bottoms using satellite imagery (Google Earth $\odot$ ) with a spatial grid to assign a binary character with the Geographic Information System ArcMap 10.1 [36], where 1 represents rocky bottoms and 0 stands for sand. The same approach was used to include the presence of rhodolith beds. The MaxEnt models were run at a resolution of $9 \mathrm{~km}$ of pixel using $75 \%$ of the occurrences as training data to build the predictions, and the other $25 \%$ to assess the accuracy of the final models. Validation of the models was performed using the area under the receiver operating characteristic curve (AUC), where AUC values equal or above 0.8 indicated reliable predictive models. The presence of the studied coral in each model was defined using the 10-percentile training presence logistic threshold [37]. 


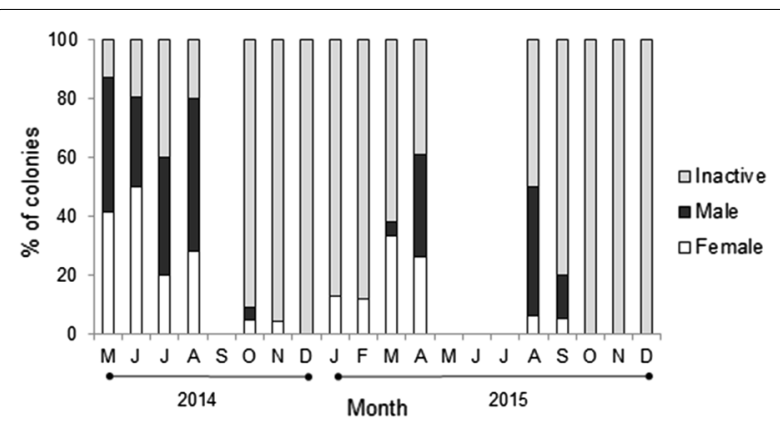

Fig. 3 Sex proportion of the coral Porites sverdrupi evaluated from May 2014 to December 2015. Missing bars represent unavailable data

\section{Results \\ Reproductive biology}

Porites sverdrupi is a gonochoric coral, as a single colony produces only one type of gamete and hence can be considered as either female or male. Gametes developed during the summer and were located within the mesenteries and, when mature, they were placed near the gastrovascular cavity. Only 120 colonies (33.8\%) out of the 355 collected presented gametes and were assigned to a specific sex (Fig. 3), suggesting seasonality in the coral's gametogenesis. Of the reproductively active colonies, $16.3 \%$ were females and $17.5 \%$ males, and the sex ratio did not significantly differ from 1:1 throughout the two years of study (Chi square test, $X^{2}=0.1333$, g.l. $=1, \mathrm{p}=0.7150$ ). No gametes were observed in the remaining 235 colonies $(66.2 \%)$, so they were considered as reproductively inactive throughout the 20 months of sampling.

Gamete development was asynchronous for both female and male colonies (Fig. 4). Female gametes were first observed in January and February 2015, although rarely (less than $2 \%$ of the analyzed colonies), while spermaries were first observed in March 2015. Mature ova and spermaries as well as planulae were observed from June to August in both studied years.

\section{Oogenesis}

Four maturity stages were observed in P. sverdrupi (Table 1, Additional file 1: Fig. S1). Most female colonies produced only one oocyte per polyp, and when two oocytes were observed in one single polyp, both were immature (stages I or II). Stage I oocytes were characterized as round cells with a mean diameter of $17.51 \pm 1.45 \mu \mathrm{m}$, big nuclei and a thin layer of cytoplasm. Stage II cells had a cell diameter of $62.01 \pm 3.85 \mu \mathrm{m}$, and cells were oval with larger nuclei located in the center of the cell. Stage III oocytes had an average diameter of $173.15 \pm 13.53 \mu \mathrm{m}$, bigger nuclei and had symbiotic dinoflagellates located

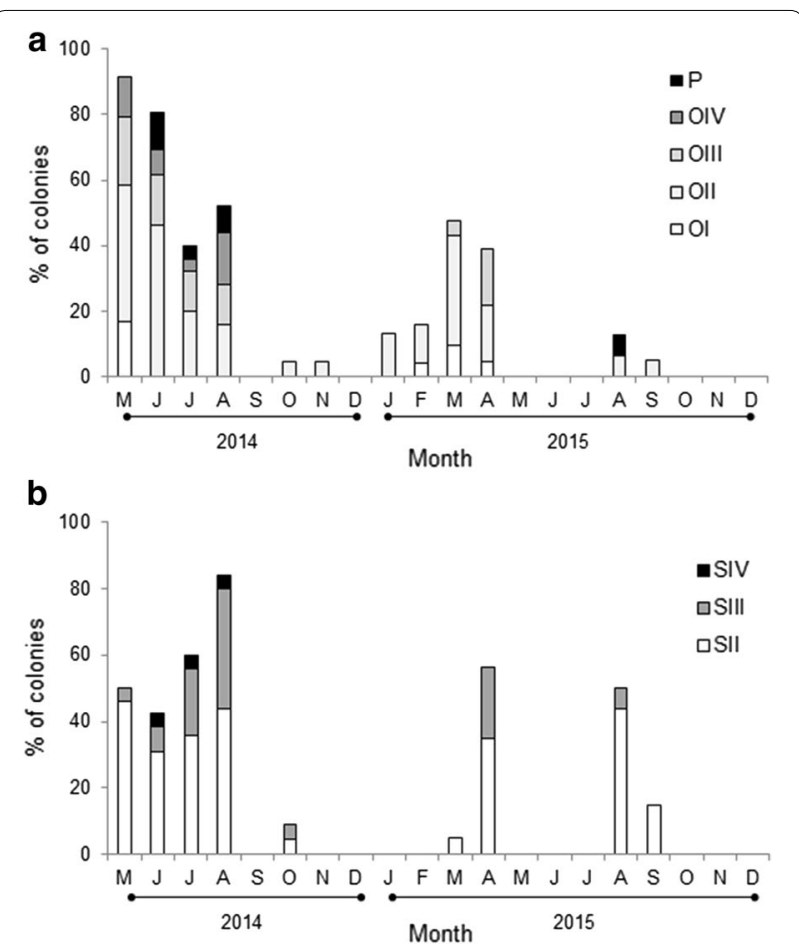

Fig. 4 Monthly proportion of colonies with evidence of gametes per maturation stages. a Monthly proportion of oocytes (Ol: oocyte I, OII: oocyte II, OIII: oocyte III, OIV: oocyte IV) and planulae (P); b monthly proportion of spermaries (SII: spermary II, SIII: spermary III, SIV: spermary IV)

in the cell's periphery. In late stage III oocytes, some lipid vacuoles could be distinguished. In these cells, there was an evident increase in their size (mean diameter $=214.61 \pm 25.67 \mu \mathrm{m}$ ) and symbiotic dinoflagellates were observed around the gamete. Only two ova in different coral colonies were observed (stage IV) near the polyp's gastric cavity and had a size $<300 \mu \mathrm{m}$. They presented vacuolated cytoplasms, symbiotic dinoflagellates both surrounding them and within their cytoplasms, and the nucleus was observed in the periphery of the cell.

\section{Spermatogenesis}

Spermatozoa in stages II, III and IV were observed, and these differed in the number, size, and shape of cells within the tubes (Additional file 2: Fig. S2). Stage II spermatozoa had big round cells inside a tube or sac. Stage III spermatozoa had more rounded cells with smaller sizes than those found in stage II cells. Male gamete maturation was observed when the cells started congregating along the tube's periphery, leaving an empty space called lumen in the center. In late III spermaries, this lumen began to be occupied with the tails of maturing cells. 
Table 1 Mean, maximum, and minimum cell and nucleus diameters recorded in Porites sverdrupi oocytes from May 2014 to December 2015

\begin{tabular}{lccccccc}
\hline Oocyte stage & $\mathbf{N}$ & Mean cell diameter $(\mu \mathrm{m})$ & $\begin{array}{l}\text { Min cell } \\
\text { diameter }(\mu \mathrm{m})\end{array}$ & $\begin{array}{l}\text { Max cell } \\
\text { diameter }(\mu \mathrm{m})\end{array}$ & $\begin{array}{l}\text { Mean nucleus } \\
\text { diameter }(\mu \mathrm{m})\end{array}$ & $\begin{array}{l}\text { Min nucleus } \\
\text { diameter }(\mu \mathrm{m})\end{array}$ & $\begin{array}{l}\text { Max nucleus } \\
\text { diameter }(\mu \mathrm{m})\end{array}$ \\
\hline I & 11 & $17.51 \pm 1.45$ & 10.64 & 24.65 & $5.16 \pm 0.35$ & 3 & 7 \\
|| & 54 & $62.01 \pm 3.85$ & 19.49 & 130.36 & $21.36 \pm 1.09$ & 9 & 45 \\
III & 16 & $173.15 \pm 13.53$ & 112.13 & 285.53 & $36 \pm 3$ & 22.44 & 64.5 \\
Late III & 2 & $214.61 \pm 25.67$ & 188.94 & 240.28 & $61.59 \pm 15.27$ & 46.32 & 76.87 \\
IV & 2 & $335 \pm 33.5$ & 301.45 & 368.56 & $69.58 \pm 1.90$ & 71.49 & 67.68 \\
\hline
\end{tabular}

Data is expressed as mean values \pm standard error

Mature spermatozoa were distinguished by the presence of flagellated cells disposed in a "bouquet" form, where the tails from the spermatozoa were arranged to one side of the tube.

\section{Planulae}

Brooded larvae were recorded from June to August in both studied years, and their average diameter was $297.87 \pm 21.38 \mu \mathrm{m} \quad(\mathrm{n}=10)$. The largest measured embryo was seen in August 2014 and measured $415.08 \pm 21.38 \mu \mathrm{m}$, while the smallest one was seen in June 2014 and measured $180.5 \pm 21.38 \mu \mathrm{m}$. Endosymbiotic cells were observed in the endoderm of all measured larvae (Additional file 3: Fig. S3).

\section{Reproduction and environmental conditions}

During the two years of study sea surface temperature at Isla Catalana ranged from 21 to $33^{\circ} \mathrm{C}$. Photosynthetically active radiation values varied between 28.58 and 62.21 Einstein $\mathrm{m}^{-2} \mathrm{day}^{-1}$, while water transparency $(\mathrm{kd})$ monthly mean was from 0.03 to $0.21 \mathrm{~m}^{-1}$, and chlorophyll a concentration fluctuated from 0.17 to $2.82 \mathrm{mg} \mathrm{m}^{-3}$ (Fig. 5). The highest temperatures, irradiances, and water transparency values, as well as the lowest chlorophyll-a concentrations occurred during the warm season from June to August and extended to November in both years, with SST ranging from 26 to $33^{\circ} \mathrm{C}$.

Reproduction in Porites sverdrupi is statistically significantly correlated to SST and PAR and there was a positive lag between these variables and maturation of gametes (Table 2). Notably, immature oocytes (stages I, II, and III) were observed in March, when SST and PAR values were around $24{ }^{\circ} \mathrm{C}$ and 50 Einstein $\mathrm{m}^{-2}$ day $^{-1}$ respectively, three months before the highest temperatures (Fig. 5). As temperature and irradiance increased (within 2 months, Table 2), gametes matured and both stage IV oocytes and planulae were observed during the warmest months from June to August (lag =0, Table 2), with SST ranging from 29 to $33{ }^{\circ} \mathrm{C}$, and irradiances from 55 to 62 Einstein $\mathrm{m}^{-2}$ day $^{-1}$. Mature male gametes (spermatozoa) were observed one month (May) before the highest STT and irradiances (Table 2).

Female gamete maturation was statistically significantly correlated to water transparency (Table 2), at kd values from 0.05 to $0.15 \mathrm{~m}^{-1}$. Planulae were observed at a $\mathrm{kd}$ below 0.06, during summer months (June to August).

Lastly, immature gametes (stages I and II) were mainly observed after the months with the highest chlorophyll a concentrations and lowest temperatures (Fig. 5). Even though correlations were significant with chlorophyll $a$, there was no evident temporal pattern with any of the gametes' maturity stages as lags did not exhibit a chronological order (Table 2).

\section{Status of the coral Porites sverdrupi}

Validation of the statistical models showed that they were precise when predicting the presence of the species, with areas under the receiver operating characteristic curve (AUC) of 0.993 . The ecological niche analysis suggested that in the years before extinction events (before the 1990's, Table 3), P. sverdrupi was distributed in shallow waters next to rocky coasts on rhodolith beds.

The resulting predictive models suggest that $P$. sverdrupi pre 1990's populations inhabited from Islas Marias $\left(21^{\circ} \mathrm{N}\right)$ to Isla Angel de la Guarda $\left(29^{\circ} \mathrm{N}\right)$, with an area of $15,552 \mathrm{~km}^{2}$ (Fig. 6a). After the first reported local extinctions (1990's), the area of presence of the species was reduced to $3159 \mathrm{~km}^{2}$ in the central GC, from Isla San Diego $\left(25^{\circ} \mathrm{N}\right.$, Fig. $\left.6 \mathrm{~b}\right)$ to El Barril $\left(27^{\circ} \mathrm{N}\right)$. The last model constructed with extant populations limits the coral presence mostly to a few insular areas, from Isla Cerralvo (24 $\mathrm{N})$ to Concepcion Bay $\left(26^{\circ} \mathrm{N}\right)$. The current area occupied by $P$. sverdrupi is $891 \mathrm{~km}^{2}$, less than $6 \%$ of its original distribution (Fig. 6c).

\section{Discussion}

\section{Reproductive biology of Porites sverdrupi}

Porites sverdrupi is a gonochoric brooding coral, one of the least common combinations between reproductive mode and sexual pattern among Scleractinia [2, 3, 38, 


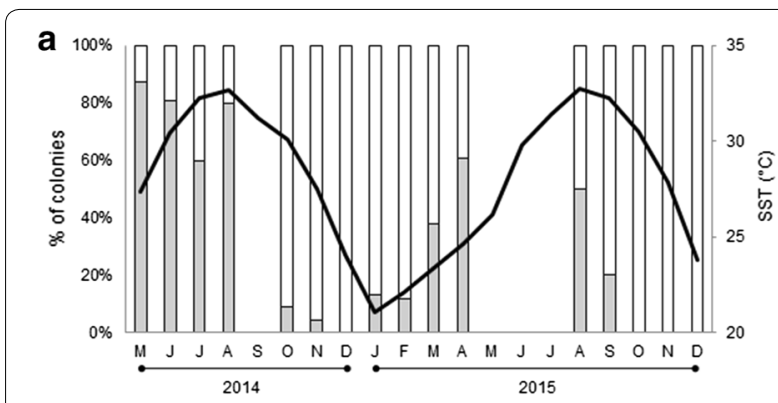

b
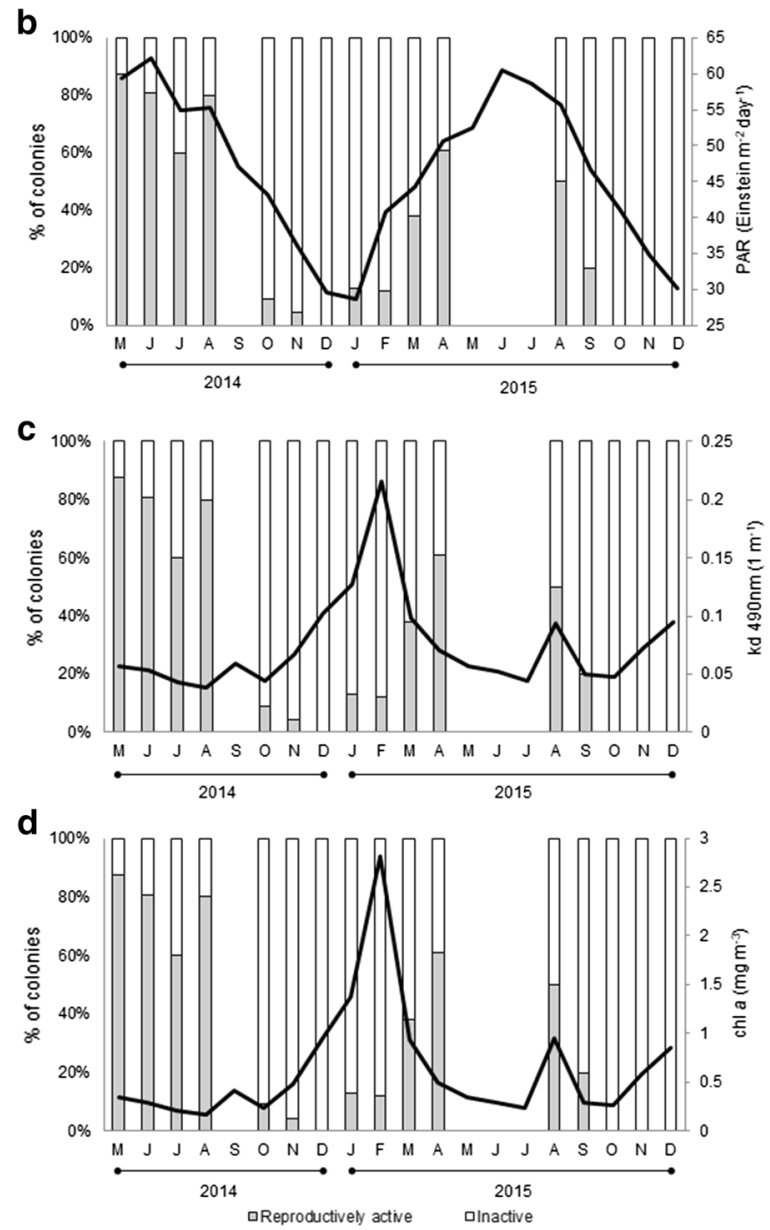

Fig. 5 Study site's monthly percentages of colonies with and without reproductive activity along with mean monthly values of: a sea surface temperature, $\mathbf{b}$ photosynthetically active radiation, $\mathbf{c}$ water transparency, and $\mathbf{d}$ chlorophyll a concentration

39]. As gamete development is asynchronous, it is possible that reproductively inactive colonies during the 2014 and 2015 reproductive period may be immature or may have not started yet this process and hence gametes could not be observed, while in other months, reproduction does not take place. These reproductive characteristics are congruent with the recognized bio geographical traits of the genus in which most Porites species from the Indo-Pacific are primarily gonochoric [40]. Also, one or two larvae may be produced per polyp each one containing their own symbiotic dinoflagellates, suggesting a vertical transmission from the mother colony, coinciding with previous observations that the ETP scleractinians predominantly vertically inherit their symbiotic dinoflagellates [3]. It is also congruent with the observation of Szmant [41] that species of this genus with small adult sizes $(<30 \mathrm{~cm}$ of diameter) are usually brooders in the Caribbean. Porites sverdrupi is a coral whose colonies are small (usually less than $10 \mathrm{~cm}$ in maximum diameter [14, 42]; pers. observ.), and in our study collected colonies had at least $5 \mathrm{~cm}$ in their maximum diameter. The species is also closely related to $P$. panamensis and to the Caribbean Porites furcata and Porites divaricata [43, 44], all of which are gonochoric brooders. This strengthens the idea that the reproductive pattern in Porites species is not only a bio geographical trait, but also an evolutive and prevalent one [39] that reinforces its evolutive relationship with the Caribbean Porites species [44]. It also coincides with previous studies that suggest that Porites species $[9,13,37]$ share similar reproductive traits within the region, like consistent gonochorism [39].

In several coral species, reproduction depends on colony size rather than age, and mature coral colonies usually stop reproducing when fragmented, although they become active again upon reaching a certain size $[2,45]$. Unlike other Porites species where reproduction has been observed only in bigger colonies (e.g. P. lobata mean reproductive colony size is of $0.036 \mathrm{~m}^{2}$ for males and $0.508 \mathrm{~m}^{2}$ for females [21]), P. sverdrupi is a small coral and thus may reach sexual maturity at smaller sizes (less than $10 \mathrm{~cm}$ diameter), resulting in an early reproductive age. As currently there are no reports characterizing the growth parameters of the species, and, considering that its close congener P. panamensis (endemic to the ETP) has a mean linear extension (e.g. growth in $\mathrm{cm}$ ) of $0.91 \pm 0.29 \mathrm{~cm}$ year $^{-1}[46]$, it can be inferred that $P$. sverdrupi colonies in this study must be at least 5 years old, thus, sexual maturity is reached with a size of at least $5 \mathrm{~cm}$ of maximum diameter. However, it is important to mention that further research about the species growth parameters are required to confirm this suggestion.

Also, P. sverdrupi exhibited a sex ratio of 1:1 throughout the study. Martínez-Castillo et al. [47] found that the species has high genetic variability despite being an endemic scleractinian undergoing extinction, suggesting that this coral's unexpected genetic variation is due to a high rate of effective sexual reproduction. A sexual ratio of $1: 1$ is considered an optimal ratio as it enhances the possibility of effective sexual reproduction as colonies have a bigger probability of achieving fertilization [2], unlike coral communities where colony fragmentation 
Table 2 Cross-correlations between each gamete stage and mean monthly values of sea surface temperature (SST), photosynthetically active radiation (PAR), light attenuation coefficient (kd) and chlorophyll-a concentration (Chla)

\begin{tabular}{|c|c|c|c|c|c|c|c|c|c|c|c|c|}
\hline \multirow[t]{2}{*}{ Gamete } & \multicolumn{3}{|l|}{ SST } & \multicolumn{3}{|l|}{ PAR } & \multicolumn{3}{|l|}{ kd } & \multicolumn{3}{|l|}{ Chla } \\
\hline & Lag & $r$ & $\mathbf{P}$ & Lag & $r$ & $\mathbf{P}$ & Lag & $r$ & $P$ & Lag & $r$ & $\mathbf{P}$ \\
\hline Oocyte I & 3 & -0.67 & $0.0482^{*}$ & 3 & -0.83 & $0.0056^{*}$ & 3 & 0.76 & $0.0166^{*}$ & 3 & 0.74 & $0.0225^{*}$ \\
\hline Oocyte II & 3 & -0.71 & $0.0333^{*}$ & 3 & -0.63 & 0.0680 & 3 & 0.67 & $0.0498^{*}$ & 3 & 0.64 & 0.0650 \\
\hline Oocyte III & 3 & -0.73 & $0.0254^{*}$ & 0 & 0.75 & $0.0048^{*}$ & 3 & 0.73 & 0.052 & 4 & 0.90 & $0.0022^{*}$ \\
\hline Oocyte IV & 1 & 0.44 & 0.1795 & 0 & 0.63 & $0.0280^{*}$ & 0 & -0.48 & 0.1175 & 3 & -0.15 & 0.7071 \\
\hline Planuale & 0 & 0.70 & $0.0118^{*}$ & 0 & 0.67 & $0.0182^{*}$ & 0 & -0.38 & $0.0227^{*}$ & 5 & 0.90 & $0.0022^{*}$ \\
\hline Spermary II & 0 & 0.68 & $0.0155^{*}$ & 2 & 0.67 & $0.0282^{*}$ & 3 & -0.30 & 0.4373 & 5 & 0.87 & $0.0050^{*}$ \\
\hline Spermary III & 0 & 0.56 & 0.0605 & 1 & 0.57 & 0.0687 & 0 & -0.51 & 0.0881 & 4 & 0.89 & $0.0034^{*}$ \\
\hline Spermary IV & 0 & 0.63 & $0.0281^{*}$ & 1 & 0.71 & $0.0152^{*}$ & 0 & -0.48 & 0.1160 & 3 & -0.15 & 0.7071 \\
\hline
\end{tabular}

Lags represent months

* Asterisks show significant correlations

Table 3 Oceanographic variables that explain $90 \%$ of the potential distribution Maxent models built for $P$. sverdrupi

\begin{tabular}{|c|c|c|}
\hline Variable & Contribution to the model (\%) & $\begin{array}{l}\text { Cumulative } \\
\text { contribution } \\
\text { to the model (\%) }\end{array}$ \\
\hline \multicolumn{3}{|c|}{ First model: historical distribution (pre-1990's) } \\
\hline Depth & 44 & 44 \\
\hline Presence of rocky coast & 18.9 & 62.9 \\
\hline Presence of rhodolith beds & 15 & 77.9 \\
\hline Primary productivity (max) & 4.1 & 82 \\
\hline Salinity (min) & 3.4 & 85.4 \\
\hline Nitrate concentration (min) & 3.2 & 88.6 \\
\hline Salinity range & 2 & 90.6 \\
\hline \multicolumn{3}{|c|}{ Second model: distribution after the first local extinctions } \\
\hline Presence of rocky coast & 30.1 & 30.1 \\
\hline Depth & 25.4 & 55.5 \\
\hline Presence of rhodolith beds & 15.1 & 70.6 \\
\hline Salinity range & 4.9 & 75.5 \\
\hline Dissolved oxygen (max) & 4.8 & 80.3 \\
\hline Mean PAR & 3.8 & 84.1 \\
\hline Primary productivity (max) & 3.4 & 87.5 \\
\hline Alkalinity range & 3.4 & 90.9 \\
\hline \multicolumn{3}{|c|}{ Third model: distribution up to date } \\
\hline Presence of rhodolith beds & 70.2 & 70.2 \\
\hline Presence of rocky coast & 13.1 & 83.3 \\
\hline Depth & 7.1 & 90.4 \\
\hline
\end{tabular}

promotes a higher proportion of clones (and hence of a single sex) with the consequent decrease in the genetic variation [9].

Brooding corals limit their production of eggs as larvae develop within the polyp, thus, having a limited internal space for their maturation [13] which may explain the limited number of larvae produced per polyp in P. sverdrupi. Gamete production is a metabolically expensive process where female gamete maturation requires high amounts of energy, therefore, production of a single oocyte per polyp in $P$. sverdrupi may ensure the energy supply for gamete development and further larvae maintenance [48]. Furthermore, larvae released by brooding corals may recruit in the same population (self-recruitment), as they metamorphose into primary polyps within minutes to hours of planulation [49], which may as well 


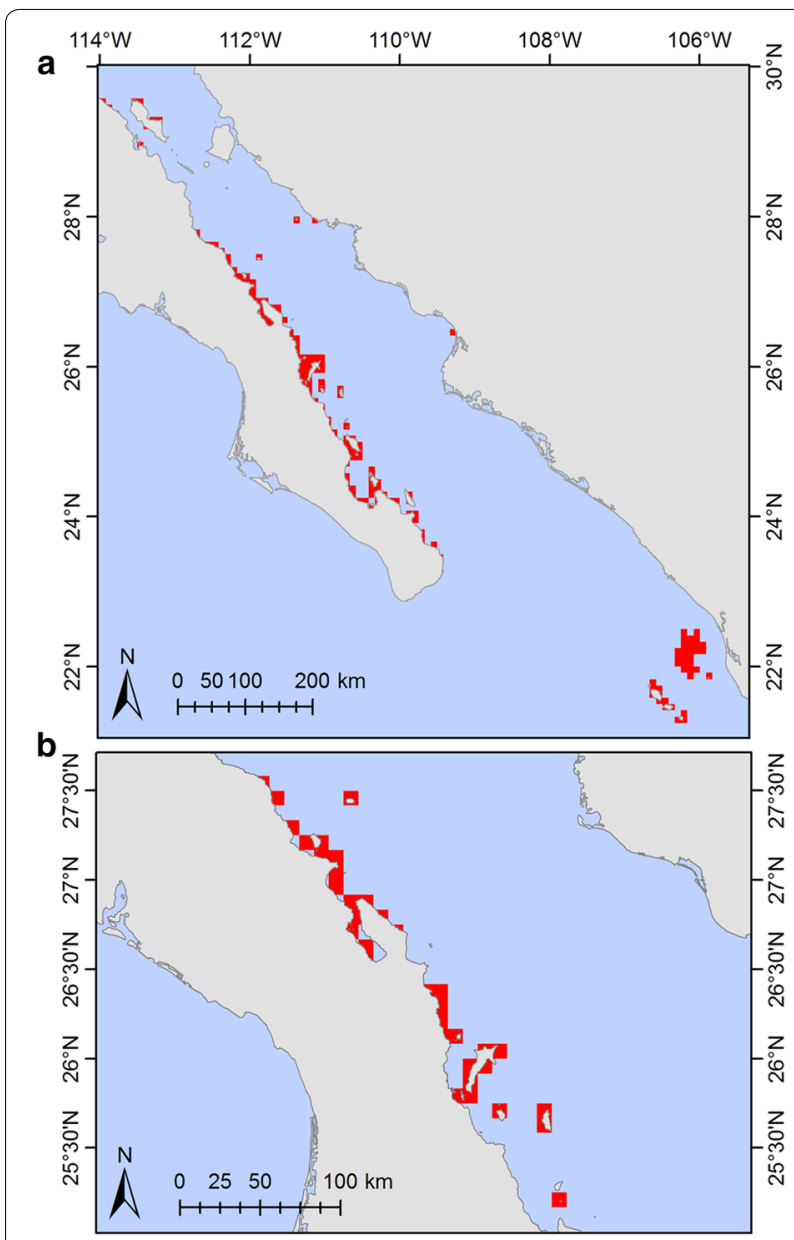

C

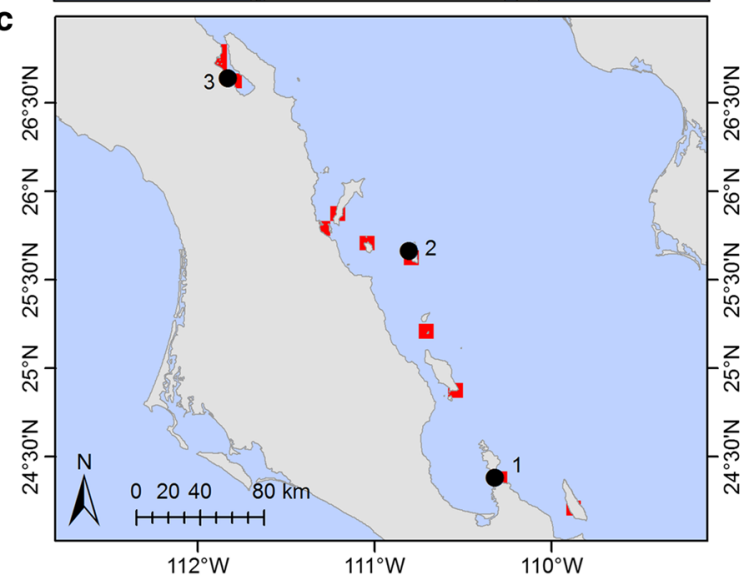

Fig. 6 Changes in the distribution of Porites sverdrupi according to the potential distribution models. a Historical distribution, b distribution of the species after the first extinction events, c distribution of extant populations where marks represent confirmed living populations: 1-San Lorenzo Channel, La Paz Bay; 2-Isla Catalana (study site), Loreto Bay; 3-El Requeson, Concepcion Bay. Red squares are areas where the potential distribution models indicate the presence of the species limit their dispersion and ability to recruit into new sites [3]. In the present study, P. sverdrupi planulae exhibited sizes $(297.87 \pm 21.38 \mu \mathrm{m})$ similar to those observed in $P$. panamensis from Panamá and the Southern Mexican Pacific $(322 \pm 11.25 ;>300 \mu \mathrm{m}$ respectively $[13,21])$, hence, as suggested by Martínez-Castillo et al. [47], they behave in the same way which causes a limited genetic exchange among its populations. Therefore, local recruitment along with coral fragmentation are processes contributing to the survival and persistence of the species in the area, underscoring the importance of sexual reproduction in this endemic species.

\section{Reproduction and environmental conditions}

Reproduction in corals is driven by a combination of environmental signals that control timing in physiological processes that lead to gamete maturation [39], therefore, reproductive activity is triggered with "optimal environmental conditions", constraining this process to just a few months as seen in other coral species [45]. In this study, we report significant correlations with positive lags (meaning that gamete maturation occurs one or a few months after environmental conditions changed) among gamete maturity stages and both temperature and light. Temperature has been reported as the most important environmental control on coral reproduction since it regulates metabolic procedures of the organisms [50]. An abnormal increase in temperature may reduce coral fecundity, quality of oocytes, successful fertilization and larvae survival [51]. During the two years of study (2014-2015), a strong ENSO event influenced the region $[7,8]$, with temperatures reaching $+3{ }^{\circ} \mathrm{C}$ of the annual maximum from June to September [52], which possibly altered the reproductive activity of $P$. sverdrupi as strong ENSO events, depending on their severity, may diminish or inhibit the reproductive activity [53]. However, even during this abnormal increase in sea surface temperature (the so called El Niño "Godzilla"), gametes and larvae were observed in both years during the months when peak temperatures (June to August) reached the $32.8{ }^{\circ} \mathrm{C}$ $\left(+3{ }^{\circ} \mathrm{C}\right.$ from the mean annual maximum SST [52]), reinforcing the idea that brooding is a key trait to ensure reproduction even during adverse environmental conditions as maintenance of larvae within the mother colony ensures their survival until they are released.

Light is also an important environmental factor for coral development as it determines the amount of energy that the organism has for its physiological processes such as reproduction [54]. In our study, gamete maturity (female and male) correlated to PAR with positive lags, while water transparency (kd) correlated to early female gamete stages and planulae only with positive lags as well. Mature gametes and planulae were observed in the 
months with the highest irradiances and most transparent waters (low values of $\mathrm{kd}$ ). At depths $\geq 15 \mathrm{~m}$, less than $20 \%$ of the incident light is photosynthetically available for the symbiotic dinoflagellates [42], and given that $P$. sverdrupi higher abundances are located at $20 \mathrm{~m}$ depth and their distribution continues up to $40 \mathrm{~m}$ with consequent low-light conditions $[14,15]$, reproduction was then linked to the months when irradiances and water transparency allowed a bigger amount of light reaching the coral colonies and when the warm temperature enhanced the photosynthetic activity of the coral's symbiotic dinoflagellates $[2,10,54,55]$, resulting in more energy available for gamete production, maturation, and further larvae maintenance.

Corals obtain energy through nutrient translocation of their symbiotic dinoflagellates' photosynthesis, from dissolved inorganic nutrients, particulate organic and inorganic matter, suspended detritus, and from plankton [56-58], hence, chlorophyll concentrations are considered as an indirect parameter of heterotrophic feeding from phytoplankton $[57,58]$. P. sverdrupi has been previously found in waters with high chlorophyll $a$ concentration [59], and in our study, gamete production started 3 months after the increase of this pigment (cold season). Therefore, prior to gamete production, corals may accumulate energy through plankton consumption.

\section{Current distribution status and conservation of Porites sverdrupi}

Local extinctions of northern and southern populations of Porites sverdrupi in the GC have been recorded since the 1990's [17]. Potential distribution models evidenced that the species is currently distributed along less than $6 \%$ of its original range. The presence of planulae observed even during a strong ENSO event $[7,8]$ implies that sexual reproduction is a fundamental process by which extant populations are prevailing. Studies with other scleractinian species inhabiting the MP show that corals can acclimatize, live, and develop in sub-optimal conditions $[53,60]$. Thus, the fact that reproduction in P. sverdrupi wasn't compromised during a strong thermal anomaly suggests that the remaining populations are acclimatizing to adverse conditions.

In order to avoid total extinction, conservation strategies must consider all the available information of the species' biology. The observed active sexual reproduction of $P$. sverdrupi in the present study, together with the specie's high genetic variability [47], supports the persistence of extant populations. Even though this scleractinian appears to be coping with current changing ocean conditions as reproduction, a physiological process sensitive to changes in the environment, was not compromised, that does not mean it will resist the more frequent and more severe thermal anomalies or ocean acidification. Under the current climate change scenario $[7,8]$, conservation of endemic species with high genetic variability [47] and with active sexual reproduction like $P$. sverdrupi is of great importance, and efforts must be directed towards preventing negative effects from both climate change and local threats [15].

\section{Conclusions}

The saffron coral, $P$. sverdrupi, is a gonochoric brooder with asynchronous gamete development, whose reproductive cycle is correlated to sea surface temperature and light. Our potential distribution models show that this scleractinian inhabits in less than $6 \%$ of its original distribution range. Despite the local extinction events that have led to this reduction, the saffron coral seems to be able to cope with current adverse oceanographic conditions, and sexual reproduction is a key process by which extant populations prevail. Finally, conservation of this endemic species relies not only on its official international and federal protection status, but also on further research on its biology that enables the development of strategies that prevent the negative effects of both climate change and local threats.

\section{Supplementary information}

Supplementary information accompanies this paper at https://doi. org/10.1186/s10152-020-00538-5.

Additional file 1: Fig. S1. Oocytes found in female Porites sverdrupi colonies: A) Stage I oocyte, B) stage II oocyte, C) stage III oocyte, D) ovum; n: nucleus, nu: nucleolus, c: cytoplasm, s: symbiotic dinoflagellate, v: vacuole.

Additional file 2: Fig. S2. Spermatocytes found in male colonies of Porites sverdrupi: A) stage II spermatozoa, B) stage III spermatozoa, C) late stage III spermatozoa, D) stage IV spermatozoa; sp: spermatozoa, s: symbiotic dinoflagellate, lu: lumen, f: flagella.

Additional file 3: Fig. S3. Larva from Porites sverdrupi; p: planula, s: symbiotic dinoflagellate, ec: ectoderm, en: endoderm

\section{Acknowledgements}

This research was funded by the Consejo Nacional de Ciencia y Tecnología (CONACyT Ciencia Básica 183534) to HRB and The PADI Foundation (program 21795) to VMC. Field work and sampling was carried out under CONAPESCA permit 031423000186. Camilo Cázarez kindly assisted in field work and sample collection. The authors kindly thank Ximena Zamacona-Montañéz, Rafael Rovirosa, and two anonymous reviewers for their valuable comments in a preliminary version of this manuscript. During the study, the first author received a Masters'scholarship from the Consejo Nacional de Ciencia y Tecnología (CONACyT, scholarship ID 332939).

\section{Sampling and field studies}

All necessary permits for sampling and observational field studies have been obtained by the authors from the competent authorities and are mentioned in the acknowledgements, if applicable. The study is compliant with CBD and Nagoya protocols.

\section{Authors' contributions}

All authors contributed to the study conception and design. Field work and sample collection were performed by VM-C. Material preparation, data 
collection and analyses were performed by VM-C, HR-B, CR-D, CAA-C, and APR-T. The first draft of the manuscript was written by VM-C and all authors commented on previous versions of the manuscript. All authors read and approved the final manuscript.

\section{Funding}

This study was funded by the Consejo Nacional de Ciencia y Tecnología (CONACyT Ciencia Básica 183534) and the PADI Foundation (program 21795).

\section{Data availability statement}

All data is contained in the manuscript. No other datasets were generated during the current study.

\section{Ethical approval and consent to participate}

No animal testing was performed during this study.

\section{Competing interests}

The authors declare that they have no conflict of interest.

\begin{abstract}
Author details
${ }^{1}$ Laboratorio de Ecología Marina, Centro Universitario de la Costa, Universidad de Guadalajara, Av. Universidad 203, Delegacion Ixtapa, 48280 Puerto Vallarta, Jalisco, Mexico. ${ }^{2}$ Laboratorio de Sistemas Arrecifales, Universidad Autónoma de Baja California Sur, Carretera al Sur km 5.5, Col El Mezquitito, 23080 La Paz, B.C.S, Mexico. ${ }^{3}$ Laboratorio Húmedo, Universidad Autónoma de Baja California Sur, Carretera al Sur km 5.5, Col El Mezquitito, 23080 La Paz, B.C.S, Mexico. ${ }^{4}$ Laboratorio Experimental de Acuacultura, Universidad Autónoma de Baja California Sur, Carretera al Sur km 5.5, Col El Mezquitito, 23080 La Paz, B.C.S, Mexico.
\end{abstract}

Received: 27 September 2019 Accepted: 29 April 2020 Published online: 12 May 2020

\section{References}

1. van Oppen MJH, Gates RD. Conservation genetics and the resilience of reef-building corals. Mol Ecol. 2006;15:3863-83. https://doi.org/10.1111/ j.1365-294X.2006.03026.x.

2. Harrison PL. Sexual reproduction of scleractinian corals. In: Dubinsky Z, Stambler N, editors. Coral Reefs: an ecosystem in transition. Netherlands: Springer; 2011. p. 59-85.

3. Glynn PW, Ault JS. A biogeographic analysis and review of the far eastern Pacific coral reef region. Coral Reefs. 2000;19:1-23. https://doi. org/10.1007/s003380050220.

4. Glynn PW. History of Eastern Pacific coral reef research. In: Glynn PW, Manzello DP, Enochs IC, editors. Coral reefs of the Eastern Tropical Pacific: Persistence and loss in a dynamic environment, vol. 8. Netherlands: Springer; 2017. p. 1-37.

5. Guzman HM, Cortés J. Reef recovery 20 years after the 1982-1983 El Niño massive mortality. Mar Biol. 2007;151:401-11. https://doi.org/10.1007/ s00227-006-0495-x.

6. Glynn PW, Riegl B, Purkis S, Kerr JM, Smith TB. Coral reef recovery in the Galápagos Islands: the northernmost islands (Darwin and Wenman) Coral Reefs. 2015;34:421-36. https://doi.org/10.1007/s00338-015-1280-4.

7. Hughes TP, Anderson KD, Connolly SR, Heron SF, Kerry JT, Lough JM, Baird AH, Baum JK, Berumen ML, Bridge TC, Claar DC, Eakin M, Gilmour JP, Graham NAJ, Harrison H, Hobbs JPA, Hoey AS, Hoogenboom M, Lowe RJ, McCulloch MT, Pandolfi JM, Pratchett M, Schoepf V, Torda G, Wilson SK. Spatial and temporal patterns of mass bleaching of corals in the Anthropocene. Science. 2018;359:80-3. https://doi.org/10.1126/science.aan80 48.

8. Eakin CM, Sweatman HPA, Brainard RE. The 2014-2017 global scale bleaching event: insights and impacts. Coral Reefs. 2019;38:539-45. https ://doi.org/10.1007/s00338-019-01844-2.

9. Glynn PW, Colley SB, Carpizo-Ituarte E, Richmond R. Coral reproduction in the Eastern Pacific. In: Glynn PW, Manzello DP, Enochs IC, editors. Coral reefs of the Eastern Tropical Pacific: Persistence and loss in a dynamic environment, vol. 8. Netherlands: Springer; 2017. p. 436-76.

10. Santiago-Valentín JD, Colley SB, Glynn PW, Cupul-Magaña AL, LópezPérez RA, Rodríguez-Zaragoza FA, Benítez-Villalobos F, Bautista-Guerrero
E, Zavala-Casas DA, Rodríguez-Troncoso AP. Regional and species specific sexual reproductive patters of three zooxanthellate scleractinian corals across the Eastern Tropical Pacific. Mar Ecol. 2018. https://doi. org/10.1111/maec.12497.

11. Fiedler PC, Lavín MF. Oceanographic conditions of the Eastern Tropical Pacific. In: Glynn PW, Manzello DP, Enochs IC, editors. Coral reefs of the Eastern Tropical Pacific: Persistence and loss in a dynamic environment, vol. 8. Netherlands: Springer; 2017. p. 59-83.

12. Chávez-Romo HE, Reyes Bonilla H. Sexual Reproduction of the coral Pocillopora damicornis in the southern Gulf of California, Mexico. Cienc Mar. 2017;33:495-550. https://doi.org/10.7773/cm.v33i4.1141.

13. Rodríguez-Troncoso AP, Carpizo-Ituarte E, Leyte-Morales GE, ChiBarragán G, Tapia-Vázquez O. Sexual reproduction of three coral species from the Mexican South Pacific. Mar Biol. 2011;158:2673-83. https ://doi.org/10.1007/s00227-011-1765-9.

14. López-Pérez RA, Reyes-Bonilla H, Budd AF, Correa-Sandoval F. The taxonomic status of Porites sverdrupi, an endemic coral of the Gulf of California. Cienc Mar. 2003;29:1-15. https://doi.org/10.7773/cm.v29i4 2.184 .

15. Chiriboga A, Edgar G, Reyes-Bonilla H. Porites sverdrupi-IUCN Red List. In: IUCN 2011. IUCN Red List of Threatened Species. V. 20011.1. 2008. https://www.iucnredlist.org/species/133512/3781140. Accessed Aug 2017.

16. Paz-García DA, Balart EF. New record of the endemic coral Porites sverdrupi (Gulf of California): do fluctuations in seawater temperature regulate its southernmost range limit? Mar Biodivers. 2015;46:499-502. https://doi. org/10.1007/s12526-015-0375-z.

17. Reyes-Bonilla H. Biogeografía y ecología de los corales hermatípicos de Pacífico de Mexico. In: Salazar-Vallejo SJ, González NE, editors. Biodiversidad Marina y Costera de Mexico. Mexico: CONABIO/CIQRO; 1993. p. 202-27.

18. Cortés J, Reyes-Bonilla H. Human influences on Eastern Tropical Pacific coral communities and coral reefs. In: Glynn PW, Manzello DP, Enochs IC, editors. Coral reefs of the Eastern Tropical Pacific: Persistence and loss in a dynamic environment, vol. 8. Netherlands: Springer; 2017. p. 549-63.

19. Hobbs JPA, van Herwerden L, Jerry DR, Jones GP, Munday PL. High genetic diversity in geographically remote populations of endemic and widespread coral reef angelfishes (genus: Centropyge). Diversity. 2013;5:39-50. https://doi.org/10.3390/d5010039.

20. Robson SJ. Changes in population densities of Porites sverdrupi, an endemic coral of the SW Gulf of California. 14th Annual Undergraduate Student Symposium (USS). Farquar College of Arts and Sciences, Nova Southeastern Unversity; 2015. p 20.

21. Glynn PW, Colley SB, Eakin CM, Smith DB, Cortés J, Gassman NJ, Guzmán HM, Del Rosario JB, Feingold JS. Reef coral reproduction in the Eastern Pacific: Costa Rica, Panamá and Galapagos Islands (Ecuador) II. Poritidae. Mar Biol. 1994;118:191-208.

22. Humason GL. Animal tissue techniques. San Francisco: W.H. Freeman and Company; 1979.

23. Prophet EB, Mills B, Arrington JB, Sobin LH. Laboratory methods in histotechnology: Hematoxylin and Eosin. Washington, DC: American Registry of Pathology and Armed Forces Institute of Pathology; 1994.

24. Zar JH. Bioestatistical analysis. New Jersey: Pearson Prentice Hall; 2010.

25. The National Aeronautics and Space Administration of the United States. GIOVANNI Database. https://giovanni.sci.gsfc.nasa.gov/giovanni/. Accessed Mar 2017

26. Davies JC. Statistics and data analysis in geology. New York: John Wiley and Sons; 1986.

27. Hammer R, Harper DAT, Ryan PD. PAST: Paleontological statistics software package for education and data analysis. Palaeontol Electronica. 2001;4:9.

28. MaxEnt software. https://www.cs.princeton.edu/ schapire/maxent.

29. Reyes-Bonilla H, Calderón-Aguilera LE, Cruz-Piñón G, Medina-Rosas $P$, López-Pérez RA, Herrero-Pérezrul MD, Leyte-Morales GE, Cupul-Magaña AL, Carriquiry-Beltrán JD. Atlas de corales pétreos (Anthozoa: Scleractinia) del Pacífico Mexicano. Mexico: Centro de Investigación Científica y de Educación Superior de Ensenada; 2005.

30. The Ocean Biogeographical Information System Database. http://www. iobis.org. Accessed Mar 2017.

31. The Global Biogeographical Information Facility Database. http://www. gbif.org. Accessed Mar 2017. 
32. Carlos-Junior LA, Neves DM, Barbosa NPU, Moulton TP, Creed JC. Occurrence of an invasive coral in the southwest Atlantic and comparison with a congener suggest potential niche expansion. Ecol Evol. 2015;5:2162-71.

33. The World Ocean Atlas Database. http://www.nodc.noaa.gov/OC5/ woa13/woa13data.html. Accessed Mar 2017

34. Lee K, Tong LT, Millero FJ, Sabine CL, Dickson AG, Goyet C, Park GH, Wanninkhof R, Feely RA, Key RM. Global relationships of total alkalinity with salinity and temperature in surface waters of the world's oceans. Geophys Res Lett. 2006:33:L19605. https://doi.org/10.1029/2006GL027207.

35. Pierrot D, Lewis DE, Wallace DWR. MS Excel program developed for CO2 system calculations. Oak Ridge: ORNL/CDIAC-105a. Carbon Dioxide Information Analysis Center, Oak Ridge National Laboratory, U.S. Department of Energy; 2006.

36. Environmental Systems Research Institute-ESRI. ArcGIS Release 10.1. Redlands, CA; 2012.

37. Radosavljevic A, Anderson RP. Making better Maxent models of species distributions: complexity, overfitting and evaluation. J Biogeogr. 2014;41:629-43. https://doi.org/10.1111/jbi.12227.

38. Richmond $\mathrm{RH}$, Hunter $\mathrm{CL}$. Reproduction and recruitment of corals: comparisons among the Caribbean, the Tropical Pacific, and the Red Sea. Mar Ecol Prog Ser. 1990;60:185-203.

39. Baird AH, Guest JR, Willis BL. Systematic and biogeographical patterns in the reproductive biology of scleractinian corals. Annu Rev Ecol Evol Syst. 2009:40:551-71. https://doi.org/10.1146/annurev.ecolsys.110308.120220.

40. Harrison PL, Wallace CC. Reproduction, dispersal and recruitment of scleractinian corals. In: Dubinsky Z, editor. Ecosystems of the world: coral reefs. Amsterdam: Elsevier; 1990. p. 133-207.

41. Szmant AM. Reproductive ecology of Caribbean reef corals. Coral Reefs. 1986;5:43-54.

42. Reyes-Bonilla H, Riosmena-Rodriguez R, Foster MS. Hermatypic corals associated with rhodolith beds in the Gulf of California, Mexico. Pac Sci. 1997;51:328-37

43. Forsman ZH, Barshis DJ, Hunter CL, Toonen RJ. Shapeshifting corals: molecular markers show morphology is evolutionarily plastic in Porites. BMC Evol Biol. 2009:9:45

44. López-Pérez RA. Revisiting the cenozoic history and the origin of the Eastern Pacific coral fauna. In: Glynn PW, Manzello DP, Enochs IC, editors. Coral reefs of the Eastern Tropical Pacific: Persistence and loss in a dynamic environment, vol. 8. Netherlands: Springer; 2017. p. 39-83.

45. Chornesky EA, Peters EC. Sexual reproduction and colony growth in the scleractinian coral Porites astreoides. Biol Bull. 1987;172:161-77.

46. Norzagaray-López CO, Calderon-Aguilera LE, Hernández-Ayón JM, ReyesBonilla H, Carricart-Ganivet JP, Cabral-Tena RA, Balart EF. Low calcification rates and calcium carbonate production in Porites panamensis at its northernmost geographic distribution. Mar Ecol. 2014;36:1244-55. https ://doi.org/10.1111/maec.12227.

47. Martínez-Castillo V, Reyes-Bonilla H, Rocha-Olivares A. High genetic diversity and limited connectivity in 2 populations of an endemic and endangered coral species: Porites sverdrupi. Cienc Mar. 2018;44:49-58. https://doi.org/10.7773/cm.v44i1.2790.

48. Hall VR, Hughes TP. Reproductive strategies of modular organisms: comparative studies of reef building corals. Ecology. 1996;77:950-63. https:// doi.org/10.2307/2265514.
49. Goodbody-Gingley G, Putron SJ. Brooding corals: planulation patterns, larval behavior, and recruitment dynamics in the face of environmental change. In: Goffredo S, Dubinsky Z, editors. The Cnidaria, past, present and future. Switzerland: Springer; 2016. p. 279-89.

50. O'connor MI, Bruno JF, Gaines SD, Halperno BS, Lester SE, Kinland BP, Weiss JM. Temperature control of larval dispersal and the implications for marine ecology, evolution, and conservation. Proc Natl Acad Sci USA. 2007;104(4):1266-71. https://doi.org/10.1073/pnas.0603422104.

51. McClanahan T, Weil E, Cortés J, Baird AH, Ateweberhan M. Consequences of coral bleaching for sessile reef organisms. In: van Oppen MJH, Lough JM, editors. Ecological studies: coral bleaching: patterns, processes, causes and consequences. Berlin: Springer-Verlag; 2009. p. 121-38.

52. CONANP. Prorama de manejo del Parque Nacional Bahía de Loreto. SEMARNAT; 2019.

53. Rodríguez-Troncoso AP, Carpizo-Ituarte E, Cupul-Magaña AL. Physiological response to high temperature in the tropical Eastern Pacific coral Pocillopora verrucosa. Mar Ecol. 2016;37:1168-75.

54. Harriot VJ, Banks SA. Latitudinal variation in coral communities in eastern Australia: a qualitative biophysical model of factors regulating coral reefs. Coral Reefs. 2002;21:83-94. https://doi.org/10.1007/s00338-001-0201-x.

55. Kleypas JA, McManus JW, Meñez LAB. Environmental limits to coral reef development: where do we draw the Line? Amer Zool. 1999;39:146-59.

56. Anthony KRN, Fabricius KE. Shifting roles of heterotrophy and autotrophy in coral energetics under varying turbidity. J Exp Mar Biol Ecol. 2000;252:221-53. https://doi.org/10.1016/S0022-0981(00)00237-9.

57. Houlbrèque F, Ferrier-Pagès $C$. Heterotrophy in tropical scleractinians corals. Biol Rev. 2009;84:1-17. https://doi.org/10.1111/j.1469185X.2008.00058.X

58. Fabricius KE. Factors determining the resilience of coral reefs to eutrophication: a review and conceptual model. In: Dubinsky Z, Stambler N, editors. Coral reefs: an ecosystem in transition. Netherlands: Springer; 2011. p. 493-505.

59. Reyes-Bonilla H, González-Romero S, Cruz-Piñón G, Calderón-Aguilera LE. Corales pétreos (Scleractinia) de la región de Bahía de los Angeles, B.C. Mexico. In: Danemann G, Ezcurra E, editors. Bahía de los Angeles: recursos naturales y comunidad. Mexico: PRONATURA, Instituto Nacional de Ecología; 2008. p. 291-317.

60. Totolero-Langarica JJA, Rodríguez-Troncoso AP, Cupul-Magaña AL, Carricart-Ganivet JP. Calcification and growth rate recovery of the reefbuilding Pocillopora species in the northeast tropical Pacific following an ENSO disturbance. PeerJ. 2016;5:e3191. https://doi.org/10.7717/peerj 3191.

\section{Publisher's Note}

Springer Nature remains neutral with regard to jurisdictional claims in published maps and institutional affiliations.

Ready to submit your research? Choose BMC and benefit from

- fast, convenient online submission

- thorough peer review by experienced researchers in your field

- rapid publication on acceptance

- support for research data, including large and complex data types

- gold Open Access which fosters wider collaboration and increased citations

- maximum visibility for your research: over $100 \mathrm{M}$ website views per year

At BMC, research is always in progress.

Learn more biomedcentral.com/submissions 